\title{
EVALUASI SIFAT FISIKA-KIMIA DAN KARAKTERISTIK ANTIOKSIDAN EKSTRAK ETANOL BIJI TIMUN SURI (Cucumis melo L.var) TERENKAPSULASI KITOSAN
}

\section{EVALUATION OF PHYSICOCHEMICAL PROPERTIES AND ANTIOXIDANT CHARACTERISTIC OF CUCUMBER SURI (CuCUmis melo L. var) SEEDS ETHANOLIC EXTRACT ENCAPSULATED IN CHITOSAN}

\author{
Fitria Mentari, Rissa Laila Vifta \\ Program Studi S1-Farmasi, Fakultas Ilmu Kesehatan, Universitas Ngudi Waluyo \\ Jalan Diponegoro 186, Gedang Anak, Ungaran, Jawa Tengah \\ e-mail : rissa_laila@yahoo.co.id
}

Diterima : 29-05-2019

Direvisi : 17-06-2019

Disetujui : 01-07-2019

\begin{abstract}
ABSTRAK
Biji timun suri (Cucumis melo L. var) mengandung beberapa senyawa metabolit sekunder yang memiliki efek sebagai antioksidan. Senyawa metabolit sekunder bahan alam umumnya memiliki bioavalailabilitas dan kelarutan yang rendah dengan air. Pembentukan nanopartikel dapat digunakan untuk mengatasi permasalahan tersebut. Penelitian bertujuan untuk mengetahui sifat fisika-kimia serta karakteristik antioksidan pada Ekstrak Biji Timun Suri terenkapsulasi kitosan. Ekstraksi Biji Timun Suri dengan metode maserasi menggunakan pelarut etanol $70 \%$. Karakterisasi fisika-kimia dilakukan dengan pengamatan persen transmitansi menggunakan Spektrofotometer UV serta penentuan ukuran partikel menggunakan Particle Size Analyzer (PSA). Pengujian karakteristik antioksidan secara in-vitro dengan metode metal ion chelating dengan pembanding Natrium-EDTA dengan metode spektrofotometri UV-Vis. Ekstraksi Biji Timun Suri menghasilkan rendemen sebesar $9,022 \% \mathrm{~b} / \mathrm{b}$. Pengamatan nilai transmitansi menghasilkan rerata \% (T) sebesar $99.5 \%$ yang menunjukkan parameter kualitatif pembentukan Nano-Kitosan Biji Timun Suri. Analisis dengan Particle Size Analyzer (PSA) menunjukkan hasil bahwa nano Kitosan-Biji Timun Suri memiliki indeks polidispersi (PI) sebesar 0.677 dan rerata ukuran diameter partikel sebesar $360 \mathrm{~nm}$. Uji aktivitas antioksidan Nano-Kitosan Biji Timun Suri menghasilkan daya antioksidan yang ditunjukkan dengan nilai $\mathrm{IC}_{50}$ sebesar 95,477 ppm dengan kategori kuat lebih besar dibandingkan

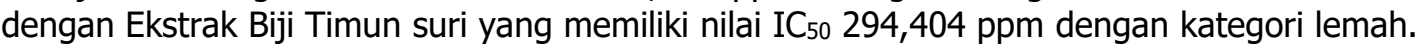

Kata kunci : antioksidan, kitosan, metal ion chealating, timun suri

\begin{abstract}
Cucumber Suri (Cucumis melo L. var) seeds extract had several secondary metabolites compound which have antioxidant activities. Secondary metabolites compound in herbal product have low bioavailability and solubility in water as usual. Nanoparticles formation can be used to solved this problem. This research was held to determine the physicochemical properties and antioxidant characteristics of Cucumber suri seeds extract encapsulated in chitosan. Extraction of Cucumber Suri seeds by maceration method using ethanol $70 \%$ as solvent. Physicochemical characterization was carried out by observing percent transmittance using a UV spectrophotometer and particle size determination using Particle Size Analyzer (PSA). Antioxidant characteristics by metal ion chelating and using sodium-EDTA as comparison by UV-Vis spectrophotometry method. Extraction of Cucumber Suri seeds giving a yield about $9.022 \%$ $w / w$. The transmittance percentages having an average about $99.5 \%$ that shown the qualitative parameters of nanoparticle formation. The Particle Size Analyzis showed that Chitosan-Cucumber Suri seeds had a polydispersion index (PI) of 0.677 and an average particle diameter size of $360 \mathrm{~nm}$. The antioxidant activities of Nano-Chitosan Cucumber Suri Seeds had antioxidant power activities by IC 50
\end{abstract}


value of 95,477 ppm with a stronger category than the Cucumber Seed Extract which had IC50 value 294,404 ppm in weak category.

Keywords : antioxidant, chitosan, cucumber suri, metal ion chelating

\section{PENDAHULUAN}

$\mathrm{N}$ anopartikel merupakan formulasi suatu partikel terdispersi pada ukuran nanometer atau skala per seribu mikron. Nanopartikel mulai dikembangkan pada bidang farmasi terutama kaitannya dengan sistem penghantaran obat. Pembentukan nanopartikel dapat meningkatkan afinitas sistem karena peningkatan luas permukaan kontak pada jumlah yang sama (Martien et al., 2012). Nanopartikel meningkatkan kelarutan senyawa, mengurangi dosis pengobatan, serta meningkatkan absorbsi target obat. Beberapa kelebihan tersebut yang mendasari pemanfaatan teknologi nanopartikel sebagai drug delivery system pada berbagai bentuk sediaan obat, kosmetik, ataupun dermatologikal (Rismana et al., 2013).

Pembentukan nanopartikel dapat dilakukan melalui teknik sederhana yakni menggunakan metode gelasi ionik. Prinsip dasar pembentukan nanopartikel melalui interaksi ionik antara enkapsulan sebagai senyawa polikation dengan anion obat (Suryani et al., 2016). Enkapsulan yang digunakan dalam pembentukan nanopartikel sebagian besar merupakan senyawa biopolimer. Biopolimer bersifat inert dan kompatibel saat dikombinasi (Schellekens et al., 2012). Biopolimer seperti kitosan memiliki kemampuan membentuk jaringan berupa matriks, beads, dan patch (Martien et al., 2012). Pada proses gelasi ionik, kitosan membentuk polikation ammonium yang secara ionik berinteraksi dengan suatu aion obat (Vllasaliu et al., 2010; Stoica et al., 2013). Interaksi ionik tersebut diikuti dengan pembentukan amonium bebas yang dapat mengganggu stabilitas nanopartikel, sehingga diperlukan suatu pengikat silang/crosslinker sebagai agen penstabil muatan (Kafshgari et al., 2011).

Formulasi nanopartikel dapat meningkatkan aktifitas farmakologis bahan alam melalui peningkatan kelarutan, sehingga tetap dapat diaplikasikan secara oral. Napsah dan Wahyuningsih, 2014 melakukan pembentukan nanopartikel ekstrak daging buah mahkota dewa menggunakan kitosan/NATPP. Nanopartikel Buah Mahkota Dewa (Phaleriamacrocarpa (Scheff) Boerl) memiliki ukuran partikel sebesar 190,9 mm. Penelitian lain oleh Ningsih et al, 2017 pada pembentukan nanopartikel G. forbesii dan G. mangostana dengan ukuran partikel $\pm 214-218 \mathrm{~nm}$, aktiiftas antioksidan meningkat, dan formula yang stabil saat diaplikasikan pada produk. Buah mengkudu yang diformulasi dalam bentuk nanopartikel terbukti meningkatkan aktiftas antioksidannya sebesar 60.5\% (Choiri et al., 2016).

Biji timun suri merupakan bagian tanaman Timun Suri (Cucumis melo L. var) yang cenderung kurang dimanfaatkan baik secara empiris maupun farmakologis. Biji Timun Suri mengandung beberapa senyawa metabolit sekunder diantaranya, flavonoid, saponin, tanin, dan alkaloid (Vifta et al., 2018). Kandungan flavonoid pada biji timun suri berpotensi sebagai kandidat antioksidan dan berbagai aktifitas farmakologis lainnya. Senyawa-senyawa metabolit sekunder bahan alam cenderung memiliki kelarutan yang rendah serta toksisitas yang tinggi sehingga dapat mempengaruhi aktifitasnya farmakologisnya (Ramadon and Mun'im, 2017). Salah satu upaya peningkatan aktifitas farmakologis pada Biji Timun Suri dapat dilakukan melalui pembentukan nanopartikel.

Penelitian ini bertujuan untuk mengkaji lebih lanjut pengaruh pembentukan nanopartikel pada ekstrak biji timun suri (Cucumis melo L. var) terhadap aktifitas antioksidan serta mengetahui karakteristik fisika-kimianya. Pengujian daya antioksidan dilakukan menggunakan metode metal ion chealating dengan prinsip peredaman radikal melalui pembentukan kompleks. Evaluasi karakteristik fisika-kimia nanopartikel menggunakan instrumentasi spektrofotometer UV-Vis untuk menentukan persen trasnsmitansi serta Particle Size Analyzer untuk mengetahui ukuran dan distribusi partikel yang terbentuk. Penelitian diharapkan 
memberikan kajian dasar pemanfaatan teknologi nanopartikel pada sediaan bahan alam yang dapat diaplikasikan lebih lanjut dalam bidang kefarmasian.

\section{METODE PENELITIAN}

\section{Alat Dan Bahan}

Alat. Seperangkat alat maserasi, blender (waring), batang pengaduk, kertas saring, alat gelas (iwaki pyrex), penangas air, waterbath (GEL), spektrofotometer UV-Vis (Shimadzu UV-1800), alat sentrifugasi, magnetic stirrer.

Bahan. Bahan uji yang digunakan adalah kitosan yang diperoleh dari Laboratorium Universitas Gadjah mada dan biji Timun Suri (Cucumis melo L. var) yang sebelumnya telah dideterminasi di Laboratorium Biologi-MIPA Universitas Diponegoro. Bahan kimia yang digunakan antara lain, $\mathrm{FeCl}_{3} 1 \%$, pereaksi dragendorff, EDTA, $\mathrm{HCl}$ p.a dari Merck ${ }^{\circledR}, \mathrm{HCl} 2 \mathrm{~N}_{2} \mathrm{H}_{2} \mathrm{SO}_{4}$ p.a, n-heksan, etil asetat, etanol $96 \%$ dari Merck $^{\circledR}$, Kitosan, NATPP dari PT. Brataco ${ }^{\circledR}$, Aquades dari CV. Bratachem $^{\circledR}$, ferrozine dari Sigma ${ }^{\circledR}$.

\section{Prosedur Penelitian}

\section{Maserasi Biji Timun Suri (Cucumis melo L. var)}

Pembuatan Ekstrak biji timun suri (Cucumis melo L.) dilakukan dengan metode maserasi yaitu dengan menimbang 1500 gram serbuk simplisia dimasukkan dalam beker gelas kemudian ditambahkan etanol 96\% (1:7.5) dibiarkan selama 2 hari dan terlindung dari cahaya matahari sambil sesekali diaduk. Kemudian ekstrak yang didapat disaring menggunakan kain flanel dan didapatkan maserat pertama. Ampas kemudian di maserasi kembali dengan menggunakan cairan penyari yang baru sebanyak $2250 \mathrm{ml}$ dan diperoleh maserat kedua dan ampas. Penguapan dilakukan dengan rotari evaporator pada suhu $50^{\circ} \mathrm{C}$ sehingga diperoleh ekstrak kental dan hitung rendemennya.

\section{Kromatografi Lapis Tipis Ekstrak Biji Timun Suri (Cucumis melo L. var)}

Penapisan fitokimia dengan menggunakan metode kromatografi lapis tipis (KLT) dilakukan untuk mengetahui kandungan metabolit sekunder yang terdapat di dalam sampel. Fase gerak yang digunakan adalah n-heksana:etil asetat dengan perbandingan 8:2. Identifikasi senyawa dilakukan dengan menggunakan beberapa pereaksi semprot, yaitu identifikasi flavonoid (uji dengan $\mathrm{H}_{2} \mathrm{SO}_{4}$ ), identifikasi alkaloid (pereaksi Dragendorff), identifikasi tanin (uji dengan $\mathrm{FeCl}_{3} 1 \%$ ).

\section{Enkapsulasi Biji Timun Suri (Cucumis melo L. var) dengan Kitosan/ NaTPP}

Pembentukan nanopartikel dengan metode gelasi ionik menggunakan enkapsulan kitosan dan penaut siang NaTPP. Ekstrak biji timun suri sebanyak 1 gram dilarutkan dalam 35 $\mathrm{ml}$ etanol p.a, dicampur $15 \mathrm{ml}$ aquades, dan ditambahkan dengan kitosan $0.2 \%$ dengan rasio volume 5:1 (Kitosan:NaTPP). Campuran distirer dengan kecepatan 400 rpm selama 20 menit. Tahap selanjutnya, ditambahkan bagian larutan NaTPP dan kembali distirrer dengan kecepatan $400 \mathrm{rpm}$ selama 20 menit hingga diperoleh campuran suspensi. Hasil formulasi yang didapatkan selanjutnya di sentrifugasi dengan kecepatan 3000 rpm selama 15 menit.

\section{Karakterisasi Nanopartikel Ekstrak Biji Timun Suri}

Uji Transmittansi : Sebanyak $1 \mathrm{mg}$ nanopartikel dilarutkan dalam aquades sampai volume $50 \mathrm{ml}$. Nanopartikel ekstrak biji timun suri diukur transmitansinya menggunakan spektrofotometer UV-Vis pada panjang gelombang $650 \mathrm{~nm}$. 
Ukuran dan Distribusi Partikel : Penentuan ukuran dan distribusi partikel (indeks polidispersi) dilakukan menggunakan instrument Particle Size Analyzer (PSA).

\section{Uji Aktifitas Antioksidan dengan Metode Metal Ion Chealating}

Penentuan Panjang Gelombang Maksimum : Larutan $\mathrm{FeCl}_{2} 2 \mathrm{mM}$ sebanyak $0,05 \mathrm{~mL}$ ditambahkan larutan Ferrozine $5 \mathrm{mM}$ sebanyak $0,2 \mathrm{~mL}$ lalu volumenya sampai $5 \mathrm{~mL}$ dengan akuabides dalam labu terukur. Larutan ini kemudian diukur dengan spektrofotometri UV-Vis pada rentang panjang gelombang 500-600 nm.

Operating time: Operating time ditentukan dengan mengambil $1 \mathrm{~mL}$ larutan sampel nano ekstrak biji timun suri, ditambah 0,05 $\mathrm{mL} \mathrm{FeCl} 22 \mathrm{mM}$, ditambahkan 0,2 $\mathrm{mL}$ larutan Ferrozine $5 \mathrm{mM}$ dan dicukupkan volemenya dengan akuabides sampai $5 \mathrm{~mL}$. Campuran larutan tersebut divortex 1 menit dan dibaca absorbansinya pada menit ke-1 sampai menit ke-35 menit pada panjang gelombang maksimal.

Pengujian : Ekstrak biji timun suri sebanyak $50 \mathrm{mg}$ dilarutkan dalam etanol pro analisis ad $50 \mathrm{~mL}$ dalam labu ukur sehingga diperoleh larutan stok 1000 ppm dan kemudian dibuat seri kadar dengan konsentrasi 20 ppm, 40 ppm, 60 ppm, 80 ppm dan 100 ppm. Sejumlah $1 \mathrm{~mL}$ sampel uji atau senyawa uji ditambah dengan $0,05 \mathrm{~mL} \mathrm{FeCl} 22 \mathrm{mM}$. Reaksi diawali dengan penambahan 0,2 mL ferrozin $5 \mathrm{mM}$, kemudian campuran digojog kuat-kuat dan dibiarkan pada suhu ruang selama 10 menit. Setelah larutan mencapai kesetimbangan, absorbansi larutan diukur secara spektrofotometri UV-Vis pada panjang gelombang maksimum.

Uji Pembanding EDTA : Uji pembanding dilakukan menggunakan larutan EDTA dengan rentang seri konsentrasi 1 ppm, 2 ppm, 3 ppm, 4 ppm, dan 5 ppm dengan tahapan pengujian yang sama dengan sampel nanopartikel ekstrak Biji Timun Suri.

\section{HASIL DAN PEMBAHASAN}

Tanaman Timun Suri yang digunakan merupakan salah satu famili Cucurbitaceae yang diperoleh dari daerah Salatiga, Jawa Tengah. Serangkaian proses pembuatan ekstrak telah dilakukan, meliputi penyerbukan simplisia, pemilihan pelarut, sampai dengan proses maserasi. Maserasi dipilih sebagai metode ekstraksi dengan pertimbangan adanya senyawa metabolit sekunder pada Biji Timun Suri (Cucumis melo L.var) yang bersifat termolabil. Maserasi merupakan metode yang mudah dan sederhana dalam ekstraksi bahan alam (Azwanida, 2015). Pada maserasi terjadi proses perendaman sampel menggunakan pelarut sesuai pada suhu kamar dalam waktu minimum 3 hari dengan bantuan pengadukan (Handa et al., 2008; Hossain et al., 2013). Ekstrak hasil maserasi dilakukan uji standarisasi meliputi parameter spesifik dan non-spesifik sesuai data yang disajikan pada Tabel 1 dan 2.

Tabel 1. Identifikasi parameter spesifik ekstrak etanol Biji Timun Suri (Cucumis melo L. var)

\begin{tabular}{|c|c|c|c|c|c|}
\hline \multirow{2}{*}{$\begin{array}{c}\text { Berat Simplisia } \\
\text { (gr) }\end{array}$} & \multirow{2}{*}{$\begin{array}{c}\text { Berat ekstrak } \\
\text { (gr) }\end{array}$} & \multirow{2}{*}{$\begin{array}{l}\text { Rendemen } \\
(\% \mathrm{~b} / \mathrm{b})\end{array}$} & \multicolumn{3}{|c|}{ Organoleptis } \\
\hline & & & Bentuk & Warna & Bau \\
\hline 1500 & 135.335 & 9.022 & Kental & Coklat & Khas \\
\hline
\end{tabular}


Tabel 2. Identifikasi parameter non-spesifik ekstrak etanol Biji Timun Suri

(Cucumis melo L. var)

\begin{tabular}{cccc}
\hline No & Parameter Uji & Uji & Hasil \\
\hline 1 & Kadar Abu & Kuantitatif & $6.29 \%$ \\
2 & Kadar Air & Kuantitatif & $0.77 \%$ \\
3 & Bebas Pelarut & Kualitatif & Bebas Etanol \\
4 & Skrining Fitokimia & Kromatografi Lapis Tipis & Flavonoid, Tanin, Alkaloid \\
5 & Total Flavonoid & Kuantitatif & $1.08 \mathrm{mg} \mathrm{QE} / \mathrm{g}$ \\
\hline
\end{tabular}

Standarisasi ekstrak merupakan salah satu cara menentukan kualitas atau mutu suatu sediaan yang berasal dari bahan alam (Zainab et al., 2016). Standarisasi ekstrak sebagai persayaratan mutu ekstrak meliputi parameter spesifik, yakni uji organoleptis serta parameter non spesifik meliputi susut pengeringan, kadar abu, kadar air, kandungan kimia ekstrak secara kualitatif dan kuantitatif (Zainab et al., 2016; Salamah and Azizah, 2013). Hasil uji organoleptis menunjukkan bahwa ekstrak yang dihasilkan kental, berwarna coklat, serta bau yang khas. Hasil skrining fitokimia menggunakan kromatografi lapis tipis menunjukkan adanya senyawa flavonoid, tannin, dan saponin sesuai dengan penelitian yang dilakukan oleh Vifta et al., 2018. Ekstrak Biji Timun Suri memilki kandungan total flavonoid yang cukup kecil, yakni sebesar 1.08 $\mathrm{mg} \mathrm{QE} / \mathrm{g}$, sehingga dapat mempengaruhi aktifitas farmakologis ekstrak Biji Timun Suri. Penerapan teknologi nanopartikel dapat digunakan sebagai upaya peningkatan aktifitas farmakologis yang berasal dari bahan alam (Ramadon and Mun'im, 2017).

Pembentukan nanopartikel Biji Timun Suri dilakukan menggunakan metode gelasi ionik. Metode gelasi ionik memungkinkan terjadinya interaksi taut silang suatu polielektrolit dengan sejumlah ion sehingga membentuk nanopartikel (Dong et al., 2013; Giri, 2016). Pada metode gelasi ionik, polisakarida kitosan dilarutkan pada larutan asam untuk membentuk kation berupa ion ammonium $\left(-\mathrm{NH}_{3}{ }^{+}\right.$) pada kitosan (Martien et al., 2012; Abdassah, 2017). Selanjutnya, campuran larutan diaduk secara kontinu dengan penambahan polianion natrium tripolifosfat. Proses kompleksasi berlangsung selama proses pengadukan melalui interaksi ionik, sehingga kitosan membentuk nanopartikel speris (Giri, 2016). Evaluasi karakteristik nanopartikel Biji Timun Suri (Cucumis melo L. var) dilakukan melalui pengukuran persen transmitansi serta penentutan ukuran dan distribusi partikel sesuai dengan hasil yang ditunjukkan oleh Tabel 3.

Tabel 3. Hasil Karakterisasi Nanopartikel Ekstrak Biji Timun Suri (Cucumis melo L. var)

\begin{tabular}{ccc}
\hline \multirow{2}{*}{ Rasio Kitosan : NaTPP } & \multicolumn{2}{c}{ Ukuran dan Distribusi Partikel } \\
\cline { 2 - 3 } & Diameter $(\mathrm{nm})$ & Indeks Polidispersi (PI) \\
\hline $5: 1$ & 360 & 0.677 \\
\hline
\end{tabular}

Nanopartikel ekstrak Biji Timun Suri (Cucumis melo L. var) memiliki ukuran diameter partikel rata-rata $360 \mathrm{~nm}$. Ukuran partikel dipengaruhi oleh rasio kitosan, natrium tripolifosfat, serta zat aktif yang terlibat selama proses gelasi ionik. Apabila jumlah zat aktif yang berinteraksi dengan kitosan sedikit, sisa zat aktif yang tidak bereaksi akan saling mengikat, sehingga menimbulkan agregasi partikel. Konsentrasi kitosan yang terlalu besar dapat meningkatkan daya gabung kitosan, sehingga mempengaruhi ukuran partikel. Selain itu, konsentrasi NaTPP yang ditambahkan juga mempengaruhi ikatan ionik selama proses kompleksasi (Yuwono et al., 2015). Faktor lain yang mempengaruhi terbentuknya ukuran partikel selama proses gelasi ionik adalah pengadukan (Fan et al., 2012).

Selain ukuran partikel, karakteristik nanopartikel ditentukan melalui indeks polidispersi (PI). Indeks polidipersi merupakan parameter yang menentukan ada tidaknya agregrasi selama pembentukan nanopartikel. Menurut Yuwono et al., 2015, distribusi ukuran partikel 
dinyatakan sebagai monodispersi apabila memasuki rentang nilai PI antara 0.01-0.7. Oleh karena itu, pembentukan nanopartikel ekstrak Biji Timun Suri (Cucumis melo L. var) menghasilkan keseragaman yang cukup baik dengan nilai PI 0.677. Ada tidaknya agregasi selama proses pembentukan ditunjukkan pula melalui karakteristik nilai transmitansi rata-rata sebesar $99.50 \pm 0.066 \%$ dengan visulisasi nanopartikel yang dihasilkan merupakan koloid jernih, seperti yang ditunjukkan pada Tabel 4.

Tabel 4. Persen Transmitansi Nanopartikel Ekstrak Biji Timun Suri (Cucumis melo L. var)

\begin{tabular}{cccc}
\hline Rentang Waktu & Warna larutan & \%T (Rata-rata) & K*\%T \\
\hline $0-60$ & Clear & $99.50 \pm 0.066$ & 99.640 \\
\hline
\end{tabular}

Uji aktifitas farmakologis Nanopartikel Biji Timun Suri dilakukan dengan mengevaluasi daya antioksidan menggunakan metode metal ion chealating. Prinsip metal ion chealating merupakan kemampuan suatu senyawa dalam mengkhelat logam Fe (Aboul-Enein et al., 2013). Senyawa tersebut akan bersaing dengan ferrozine dalam mengikat ion besi $\left(\mathrm{Fe}^{2+}\right)$. Senyawa fenolik mengikat sejumlah $\mathrm{Fe}^{2+}$, tetapi $\mathrm{Fe}^{2+}$ yang tersisa bereaksi dengan ferrozine (kromofor), membentuk kompleks yang dapat dilihat secara spektrofotometri. Ferrozine merupakan kelompok ferroin yang mempunyai kemampuan dalam membentuk kompleks dengan ion besi $\left(\mathrm{Fe}^{2+}\right)$, dimana senyawa kompleks yang terbentuk nantinya akan diganggu oleh senyawa lain yang mengkhelat logam besi tersebut (Santos et al., 2017).

Sampel uji dinyatakan mempunyai aktivitas sebagai pengkelat ion logam apabila mampu memecah kompleks Fe ${ }^{2+-}$ ferrozine bereaksi membentuk kompleks dengan ion besi $\left(\mathrm{Fe}^{2+}\right)$ yang lepas dan ditandai penurunan absorbansi kompleks $\mathrm{Fe}^{2+}$ ferrozine yang ditunjukkan melalui penurunan intensitas warna merah (Aboul-Enein et al., 2013). Data pada Tabel 5 dan 6 menunjukkan adanya peningkatan aktifitas antioksidan nanopartikel Biji Timun Suri dibandingkan dengan ekstraknya. Nanopartikel Biji timun suri menghasilkan nilai IC $_{50}$ sebesar dengan kategori antioksidan kuat, sedangkan nilai IC $_{50}$ ekstrak Biji Timun Suri sebesar 295, 404 ppm dengan kategori antioksidan lemah.

Tabel 5. Aktifitas Antioksidan Nanopartikel Biji Timun Suri (Cucumis melo L.var)

\begin{tabular}{cccrrr}
\hline No. & Konsentrasi $(\mathrm{ppm})$ & Absorbansi & $\begin{array}{r}\text { \%Aktivitas } \\
\text { Antioksidan }\end{array}$ & $\mathrm{IC}_{50}(\mathrm{ppm})$ & Kategori \\
\hline 1. & 20 & 0,342 & 18,182 & & \\
2. & 40 & 0,331 & 20,813 & & \\
3. & 60 & 0,261 & 37,560 & 95,477 & Kuat \\
4. & 80 & 0,231 & 44,737 & & \\
5. & 100 & 0,207 & 50,478 & & \\
\hline
\end{tabular}

Keterangan : Absorbansi Blanko $=0.418$

Tabel 6. Aktifitas Antioksidan Ekstrak Etanol Biji Timun Suri (Cucumis melo L.var)

\begin{tabular}{cccccc}
\hline No. & Konsentrasi (ppm) & Absorbansi & $\begin{array}{r}\text { \%Aktivitas } \\
\text { Antioksidan }\end{array}$ & $\mathrm{IC}_{50}(\mathrm{ppm})$ & Kategori \\
\hline 1. & 20 & 0,326 & 12,129 & & \\
2. & 40 & 0,329 & 11,321 & & \\
3. & 60 & 0,302 & 18,698 & 295,404 & Lemah \\
4. & 80 & 0,296 & 20,216 & & \\
5. & 100 & 0,290 & 21,833 & & \\
\hline
\end{tabular}

Keterangan : Absorbansi Blanko $=0.371$ 
Pembanding aktifitas antioksidan menggunakan EDTA yang memiliki kemampuan sebagai pengkhelat logam. EDTA merupakan ligan pengkhelat dengan afinitias kuat untuk membentuk kompleks dengan ligan. Hasil uji antioksidan yang ditunjukkan oleh Tabel 7 menunjukkan bahwa pembanding EDTA memiliki aktivitas yang lebih besar ditunjukkan dengan nilai $\mathrm{IC}_{50} 4,053 \mathrm{ppm}$ dengan kategori antioksidan sangat kuat. EDTA memiliki aktivitas sebagai pengkhelat logam Fe dikarenakan EDTA mampu berkompetisi dengan ferrozine untuk memecah ikatan kompleks $\mathrm{Fe}^{2+}$-ferrozine sehingga ion Fe terlepas dan berikatan dengan EDTA membentuk kompleks, kemudian sisa $\mathrm{Fe}^{2+}$ yang lainya akan berikatan dengan ferrozine dan memberikan penurunan absorbansi pada ferrozine (Santos et al., 2017).

Tabel 7. Aktifitas Antioksidan Pembanding EDTA (Etilen Diamin Tetra Asetat)

\begin{tabular}{cccccc}
\hline No. & Konsentrasi $(\mathrm{ppm})$ & Absorbansi & $\begin{array}{c}\text { \%Aktivitas } \\
\text { Antioksidan }\end{array}$ & IC $_{50}(\mathrm{ppm})$ & Kategori \\
\hline 1. & 1 & 0,291 & 29,710 & & \\
2. & 2 & 0,245 & 40,821 & & Sangat \\
3. & 3 & 0,234 & 43,559 & 4,053 & Kuat \\
4. & 4 & 0,205 & 50,403 & & \\
5. & 5 & 0,189 & 54,428 & & \\
\hline
\end{tabular}

Keterangan : Absorbansi Blanko $=0.414$

Grafik hubungan antara konsentrasi dengan persen penghambatan khelat pada Gambar 1 menunjukkan peningkatan aktifitas seiring dengan bertambahnya konsentrasi, baik pada ekstrak dan nanopartikel Biji Timun Suri maupun pembanding EDTA. Semakin tinggi konsentrasi, aktiiftas penghambatan khelat semakin besar. Hasil tersebut mengindikasikan bahwa semakin banyak senyawa antioksidan yang ditambahkan, semakin besar terjadinya kompetisi dengan ferrozine dalam pembentukan khelat dengan logam Fe. Berdasarkan grafik hubungan pada Gambar 1 dapat terlihat bahwa nanopartikel ekstrak Biji Timun Suri memiliki aktifitas tertinggi sebesar 50,478\% pada konsentrasi 100 ppm.

(a)

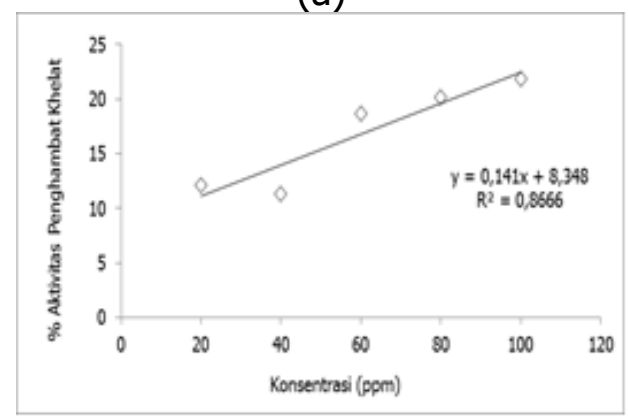

(b)

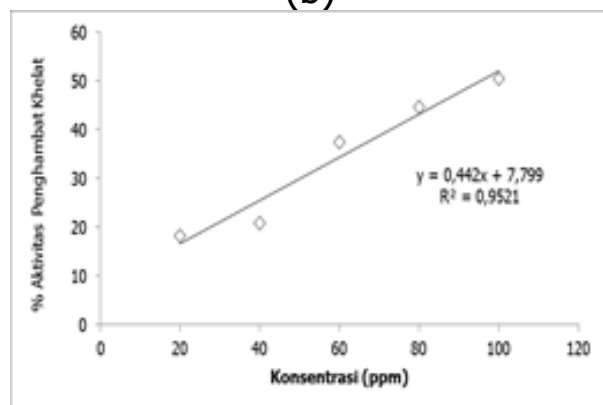

(c)

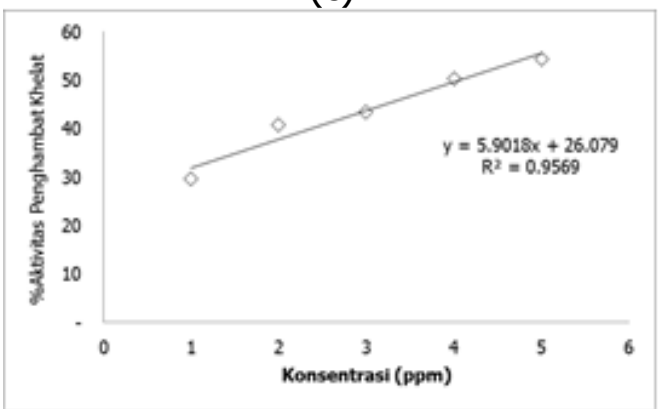

Gambar 1. Kurva hubungan antara konsentrasi dengan \% aktivitas penghambat khelat $\mathrm{Fe}^{2+-}$ ferrozine pada (a) ekstrak biji timun suri, (b) nanopartikel biji timun suri, (c) EDTA 
Daya antioksidan yang dihasilkan pada ekstrak Biji Timun Suri dan nanopartikel ekstrak Biji Timun Suri dipengaruhi adanya kandungan flavonoid yang merupakan salah satu golongan senaywa fenolik. Senyawa fenolik mempunyai kemampuan dalam mengikat radikal bebas, termasuk hidroksil, peroksil dan radikal superoksida dan dapat membentuk kompleks dengan ion logam katalitik sehingga menjadi inaktif (Milda and Embuscado, 2015). Peningkatan aktifitas antioksidan pada nanopartikel crosslink dipengaruhi oleh perubahan ukuran partikel. Ukuran partikel kecil akan menghasilkan luas permukaan yang besar, dengan demikian sejumlah senyawa fenolik seperti flavonoid yang terjerap pada permukaan nanopartikel akan lebih banyak, sehingga aktifitas antioksidan yang dihasilkan semakin besar (Charernsriwilaiwat et al., 2013; Sriyanti et al., 2017).

\section{KESIMPULAN}

Pembentukan nanopartikel pada ekstrak Biji Timun Suri (Cucumis melo L. var) dengan kitosan/NaTPP menghasilkan karakteristik fisika-kimia sebagai nanopartikel dengan nilai transmitansi sebesar $99.5 \%$, ukuran partikel $360 \mathrm{~nm}$, serta indeks polidispersi kurang dari 1 (0.677). Aktivitas antioksidan Nano-Kitosan Biji Timun Suri menghasilkan nilai $\mathrm{IC}_{50}$ sebesar 95,477 ppm dengan kategori kuat. Nilai tersebut lebih besar dibandingkan dengan Ekstrak Biji Timun (Cucumis melo L. var) yang memiliki nilai $\mathrm{IC}_{50} 294,404$ ppm dengan kategori lemah.

\section{UCAPAN TERIMA KASIH}

Ucapan terimakasih disampaikan kepada Lembaga Penelitian dan Pengabdian kepada Masyarakat (LPPM) Universitas Ngudi Waluyo yang telah memberikan pendanaan Penelitian Dosen Internal tahun Anggaran 2018 demi kelancaran dan terselesaikannya penelitian ini dengan baik.

\section{DAFTAR PUSTAKA}

Abdassah, M., 2017. Nanopartikel dengan gelasi ionik. Farmaka, 15(1), pp.45-52.

Aboul-Enein, H.Y., Berczyńsk, P. and Kruk, I. 2013. Phenolic Compounds: The Role Of Redox Regulation In Neurodegenerative Disease and Cancer. Mini Rev. Med. Chem. 13(3):38598

Azwanida, N.N., 2015. A review on The Extraction Methods Use In Medicinal Plants, Principle, Strength And Limitation. Med Aromat Plants, 4(196), pp.2167-0412.

Charernsriwilaiwat, N., Rojanarata, T., Ngawhirunpat, T., Sukma, M. and Opanasopit, P., 2013. Electrospun Chitosan-Based Nanofiber Mats Loaded with Garcinia mangostana extracts. International Journal Of Pharmaceutics, 452(1-2), pp.333-343.

Choiri, Z., Martien, R., Dono, N.D. and Zuprizal, Z., 2016. Biosintesis dan Karakterisasi NanoEnkapsulasi Ekstrak Buah Mengkudu (Morinda citrifolia) Dengan Kitosan-Sodium Tripolifosfat sebagai Kandidat Antioksidan Alami. Prosiding Simposium Nasional, Penelitian dan Pengembangan Peternakan Tropik Tahun 2016, pp.22-28.

Dong, Y., Ng, W.K., Shen, S., Kim, S. and Tan, R.B., 2013. Scalable Ionic Gelation Synthesis of Chitosan Nanoparticles for Drug Delivery in Static Mixers. Carbohydrate polymers, 94(2), pp.940-945.

Fan, W., Yan, W., Xu, Z. and Ni, H., 2012. Formation Mechanism Of Monodisperse, Low Molecular Weight Chitosan Nanoparticles By Ionic Gelation Technique. Colloids and Surfaces B: Biointerfaces, 90, pp.21-27.

Giri, T.K., 2016, Nanoarchitectured Polysaccharide-Based Drug Carrier for Ocular Therapeutics, Nanoarchitectonics for Smart Delivery and Drug Targeting, pp : 119-141

Handa SS, Khanuja SPS, Longo G, Rakesh DD, 2008, Extraction Technologies for Medicinal and Aromatic Plants, (1stedn), no. 66. Italy: United Nations Industrial Development Organization and the International Centre for Science and High Technology. 
Hossain, M.A., Al-Toubi, W.A., Weli, A.M., Al-Riyami, Q.A. and Al-Sabahi, J.N., 2013. Identification and Characterization Of Chemical Compounds In Different Crude Extracts From Leaves of Omani neem. Journal of Taibah University for Science, 7(4), pp.181-188.

Kafshgari, M.H., Khorram, M., Khodadoost, M. and Khavari, S., 2011. Reinforcement of Chitosan Nanoparticles Obtained By An Ionic Cross-Linking Process. Iran Polym J, 20(5), pp.445-456.

Martien, R., Adhyatmika, A., Irianto, I.D., Farida, V. and Sari, D.P., 2012. Perkembangan Teknologi Nanopartikel Sebagai Sistem Penghantaran Obat. Majalah Farmaseutik, 8(1), pp.133-144.

Milda, E. and Embuscado, 2015. Species and herbs: Natural Sources of Antioxidant-a mini Review. Journal of Fuctional Food. 18(B), pp : 811-819

Napsah, R. and Wahyuningsih, I., 2014. Preparasi Nanopartikel Kitosan-TPP/Ekstrak Etanol Daging Buah Mahkota Dewa (Phaleriamacrocarpa (Scheff) Boerl) dengan Metode Gelasi Ionik. Jurnal Farmasi Sains dan Komunitas (Journal of Pharmaceutical Sciences and Community), 11(1).

Ningsih, N., Yasni, S. and Yuliani, S., 2017. Sintesis Nanopartikel Ekstrak Kulit Manggis Merah Dan Kajian Sifat Fungsional Produk Enkapsulasinya. Journal of Food Technology \& Industry/Jurnal Teknologi \& Industri Pangan, 28(1).

Ramadon, D. and Mun'im, A., 2017. Pemanfaatan Nanoteknologi dalam Sistem Penghantaran Obat Baru untuk Produk Bahan Alam. Jurnal IImu Kefarmasian Indonesia, 14(2), pp.118127.

Rismana, E., Kusumaningrum, S., Bunga, P.O., Rosidah, I. and Marhamah, 2013. Sintesis dan Karakterisasi Nanopartikel Kitosan-Ekstrak Kulit Buah Manggis (Garcinia mangostana). J. Sains dan Teknol. Indones, 14, pp.189-196.

Salamah, N. and Azizah, B., 2013. Standarisasi Parameter Non Spesifik dan Perbandingan Kadar Kurkumin Ekstrak Etanol Dan Ekstrak Terpurifikasi Rimpang Kunyit. Pharmaciana, 3(1), pp.21-30.

Santos, J.S., Alvarenga Brizola, V.R., Granato, D., 2017. High-throughput Assay Comparison and Standardization For Metal Chelating Capacity Screening: A Proposal and Application. Food Chem. 214, 515-522.

Schellekens, R.C., Baltink, J.H., Woesthuis, E.M., Stellaard, F., Kosterink, J.G., Woerdenbag, H.J. and Frijlink, H.W., 2012. Film coated tablets (ColoPulse technology) for targeted delivery in the lower intestinal tract: Influence of the core composition on release characteristics. Pharmaceutical Development And Technology, 17(1), pp.40-47.

Sriyanti, I., Edikresnha, D., Rahma, A., Munir, M.M., Rachmawati, H. and Khairurrijal, K., 2017. Correlation Between Structures And Antioxidant Activities Of Polyvinylpyrrolidone/Garcinia mangostana L. Extract Composite Nanofiber Mats Prepared Using Electrospinning. Journal of Nanomaterials, 2017, 1-10, Article ID 9687896, 1, https://doi.org/10.1155/2017/9687896

Stoica, R., Şomoghi, R. and Ion, R.M., 2013. Preparation Of Chitosan-Tripolyphosphate Nanoparticles For The Encapsulation Of Polyphenols Extracted From Rose Hips. Digest Journal of Nanomaterials \& Biostructures (DJNB), 8(3).

Suryani, S., Wahyuni, W., Ariastika, D. and Rahmanpiu, R., 2016. Formulasi Nanopartikel Kurkumin dengan Teknik Gelasi Ionik Menggunakan Kitosan, Tripolifosfat dan Natrium Alginat serta Uji Stabilitasnya Secara In Vitro. Pharmauho, 2(1).

Vifta, R.L., Khotimah, S.K. and Luhurningtyas, F.P., 2018. Uji Aktivitas Antifungi Ekstrak Etanol Biji Timun Suri (Cucumis melo L.) terhadap Pertumbuhan Candida albicans secara In Vitro. Indonesian Journal of Pharmacy and Natural Product, 1(1).

Vllasaliu, D., Exposito-Harris, R., Heras, A., Casettari, L., Garnett, M., Illum, L. and Stolnik, S., 2010. Tight Junction Modulation By Chitosan Nanoparticles: Comparison With Chitosan 
Solution. International Journal Of Pharmaceutics, 400(1-2), pp.183-193.

Yuwono, T., Binarjo, A. and Priyanti, R., 2015. Pengembangan Preparasi Nanopartikel Thymoquinone-Kitosan Dengan Metode Kosolven Menggunakan Isopropil Alkohol, Pharmaçiana, Vol. 5, No. 2, pp:121-130.

Zainab, N. Sulityani, Anisaningrum, Penetapan Parameter Standardisasi Non Spesifik dan Spesifik Ekstrak Daun Pacar Kuku (Lawsonia inermis L.), 2016, Media Farmasi, Vol. 13 No. 2, pp: 212-226. 